\title{
Perceptions of Nurses about Medication Errors: A Cross-Sectional Study
}

\author{
Salim Mohamed Al Khreem ${ }^{1}$, Mugahed Ali Al-khadher ${ }^{2}$ \\ ${ }^{1}$ Student, Faculty of Nursing, Najran University, Saudi Arabia \\ ${ }^{2}$ Assistant Professor of Medical Surgical Nursing, Faculty of Nursing, Najran University, Saudi \\ Arabia
}

\begin{tabular}{|c|c|}
\hline Article Info & Abstract \\
\hline Article history: & Purpose: The aim of this study is to assess nurses perception of \\
\hline Received:19 December 2020 & $\begin{array}{l}\text { meatcation errors hurses in Maternity ana Chila Hospulat in Najran city, } \\
\text { Saudi Arabia. }\end{array}$ \\
\hline $\operatorname{Re}$ & Study Design: A cross-sectional study. \\
\hline uary 202 & $\begin{array}{l}\text { Subjects and Methods: This descriptive study was carried out among } 72 \\
\text { nurses in Maternity and child Hospital in Nairan city, Saudi Arabia. Data }\end{array}$ \\
\hline Keywords: & were collected through a questionnaire, consisting of two parts: Part 1 \\
\hline Perce & covers demographical data, which includes age, gender, educational \\
\hline Medication Errors, & $\begin{array}{l}\text { level, and years of experience and place of work in the hospital. Part } 2 \text { of } \\
\text { the questionnaire consists of (23) questions about the nurses' perception }\end{array}$ \\
\hline Nurses. & $\begin{array}{l}\text { of the causes, reporting medication error and perceptions of barriers to } \\
\text { reporting medication errors. Data was analyzing by using statistical }\end{array}$ \\
\hline Paper Type : & $\begin{array}{l}\text { package for social science (SPSS) version } 20 . \\
\text { Results: The results of the studv indicate that most of the participants had }\end{array}$ \\
\hline Research Article & $\begin{array}{l}\text { good perception about the causes of medication errors. Nevertheless, the } \\
\text { data analvsis showed that many of the participants had reporting }\end{array}$ \\
\hline Corresponding Author: & $\begin{array}{l}\text { medication errors. More importantly, the participants indicated that there } \\
\text { exist multiple barriers to reporting medication errors. Two thirds of them }\end{array}$ \\
\hline Mugahed Ali Al-khadher & $\begin{array}{l}\text { had moderate barriers to concerns over the consequences of reporting. } \\
\text { More than half of them had minor barriers to blaming nurses if patients }\end{array}$ \\
\hline Email: & $\begin{array}{l}\text { are harmed, while, about one quarter of them had major barriers to fear } \\
\text { of punishment. There were no statistically significant relation between the } \\
\text { studied nurses' perception about the causes of medication errors and } \\
\text { their characteristics }(P \text { value }>0.05) \text {. }\end{array}$ \\
\hline drmugahedalkhader@ & $\begin{array}{l}\text { Conclusions: It is concluded that nurses at Maternity and child Hospital in } \\
\text { Najran city, Saudi Arabia. Had good perception about the causes of } \\
\text { medication errors. In addition, there were no statistically significant } \\
\text { relationship between the participants' reporting medication errors and } \\
\text { their characteristics except age and years of experience. }\end{array}$ \\
\hline
\end{tabular}

\section{Introduction}

Medication administration and charting may occupy up to $33 \%$ of nursing time in the hospital setting. The medication and charting aspect of nursing practice have been greatly affected by advances in medicine and technology. New drugs, new devices for administration, and computerized systems for documenting the medication administration process present an ever-changing reality for nurses. Improving patient safety with information technology has long been a goal of clinical information systems (Flynn et al., 2012). 
Safety during patient hospitalization is considered one of the important patient rights and the first priority of the health care professionals. Errors that occur during the application of medical and nursing interventions have captured the health researcher's attention over the last decade(WHO, 2017).It is always emphasized that the medication administration process should be free from errors as possible. For this purpose, nurses need to be diligent in discouraging interruptions to prevent harm to the patients during hospitalization(Kruer et al., 2014).

Literature review indicates that medication errors cause numerous deaths per year. The reports, articles, and reviews written about medication errors have all shown that errors occur on a regular basis in hospital settings. Studies have shown that the fatal effects of medication errors have not decreased even after raising reports (Kim et al., 2011).

Nonetheless, nurses need to be supported during the medication administration process to minimize errors from the beginning of the process until the time of administration. During the time of medication administration, phone calls, patients, or other staff members should not interrupt nurses. They need to be encouraged to complete the appropriate steps to medication administration such as the medication administration record (MAR) and proper identification process (Tshiamo et al., 2015). Some interventions for reducing or preventing the medication administration error are educating and observing the nurses during the medication administration encouraging the use of medication administration records (MAR), and preventing interruptions during the administration time. Several health organizations have focused attention on medication safety and compiled recommendations for safe medication practices in inpatient environment (Spector, et al., 2012).

Medication errors are well-known problem in hospitals. Studies have shown that medication errors and adverse drug reactions (ADRs) are one of the main causes for adverse events in hospitals leading to disability and death. This constitutes up to $6.5 \%$ of hospital admission. Every year between 44,000 and 98,000 individuals die in hospitals due to medical errors (Balkhi et al., 2017). Therefore, the goal of the study is to assess nurse's perception of drug errors. Patient safety is a common goal for every healthcare provider. One of the major issues for safety is medication errors. It is important indicator of health care delivery system because potential risk to patients. It is only within the past decade that studies have linked errors to medical-nursing personnel to adverse events and adverse outcomes for patients (Benjamin, 2003).

Medication errors (ME) alone account for an estimated 7,000 deaths annually, and ME is defined as: "any preventable event that may cause or lead to inappropriate medication use or patient harm while the medication is in the control of the health care professional, patient, or consumer" and this error may be committed by physician, pharmacist or nurse(Cousins \& Heath, 2008).Medication errors could occur during (ordering, transcribing, dispensing, administering, or monitoring) of medication process. In hospitals, three fourth of ME occurs at the prescribing and administration stages. However, prescription errors occur at rate 0.1 - 0.3 errors per patient per day (Kaushal et al., 2001).

The types of ME commonly encountered in the medication process have been examined in various studies. The most reported errors are wrong dose, wrong choice, wrong drug, known allergy, missed dose, wrong time, wrong frequency, wrong technique, drug-drug interaction, wrong route, and extra dose, failure to act on test, equipment failure, inadequate 
monitoring, preparation error, and others. According to studies made in the USA, the most common types of MEs were the following: omission error, improper dose/quantity, prescribing error, unauthorized drug, wrong time, extra dose, wrong patient, wrong drug preparation, wrong dosage form, wrong route, and wrong administration technique (Buckley et al., 2007).

In Australia, a self-administer questionnaire had been used to get information about nurses perception for ME. Nurses said that dose at wrong time, missed dose, wrong rate (too fast or too slow), wrong duration, over and under dosage, extra dose and wrong strength are the main types of medication errors from the highest occurring to the least respectively(Deans, 2005).

In a study conducted in Saudi Arabia in 2006, 10000 patient's files were reviewed and 2627 medication errors were identified. The spectrum of these errors was variable; improper doses, over, under, or extra dose, wrong drug, wrong rout of administration, wrong duration, dose omission, wrong strength, or wrong dosage form (Dibbi et al., 2006). In Jordan 200 registered nurses (RN) were asked to answer questionnaire about ME,126 nurses completed the questionnaire, and results showed that nurses perceived the following as the main types of AME: Wrong patient (26\%), wrong dose (22\%), no or wrong date (12\%), wrong drug $(9.5 \%)$, wrong time $(8.7 \%)$, wrong documentation $(6.3 \%)$, wrong route of administration $(4.7 \%)$, no medication(omission of the dose) (4.7\%), wrong frequency of the doses $(3.1 \%)$ and finally changing of medication (1.5\%)( Al-Shara, 2011).

In Australia,154 (RN), completed The Medication Error Questionnaire (MEQ) that was developed by the researcher, and the study revealed that ME occurs mostly when; the main cause lead to ME was failure to identify the patient (35\%), followed by fatigue and exhaustion $(25 \%)$. Results also revealed the majority of nurses noted that most medication errors were not reported because of fear of reaction from nurse managers and co-workers. Also, perceived causes of drug errors were doctors' handwriting is difficult to read or illegible, nurses are distracted, and nurses are tired and exhausted (Al-Sarawan, 2014).

A descriptive cross-sectional study was conducted in Turkey in 2014. One hundred seventy four nurses were asked to report their views on the causes and reporting of ME. Results showed the main causes for ME were tiredness and exhaust, the seconds main reason was distraction by patients, other co-workers or events on the unit, nurse fails to check the patient's name band with the (MAR), confusion due to similarity of two drug names, dose miscalculation, physician prescribes the wrong dose, nurse sets up or adjusts an infusion device incorrectly, confusion of the different types and functions of infusion devices, physician's illegible hand writing, and finally ME occurs due to medication labels/packaging are of poor quality or damaged (Güneş et al., 2014).

\section{Methodology and Procedures}

In this study, a descriptive cross-sectional design was employed. This study was conducted in Maternity and Children Hospital in Najran City, Saudi Arabia. The period of the study extended for two months during 2020. All nurses that were available in hospital during the data collection period were invited to participate in the study. Convenience sampling method was used, and all nurses that were available in the selected departments of the 
hospital during the data collection period were invited to participate in the study. Consent was obtained from the participants and they all agreed to participate in the study. Data were collected using questionnaire consisting of two parts. Part one consisted of demographic data of participants including age, gender, educational level, and years of experience. Part two of the questionnaire consisted of 17questions about the nurses' perception of the causes of medication errors and nurses 'reporting of medication errors. A pilot study was carried out in the study setting on $10 \%$ of the study sample to identify practical or local problems that might potentially affect the research process. A packaged computer analysis program, statistical package for the social science (SPSS Version 20) was used for statistical analysis of data. Descriptive measures, including frequency, percentage, arithmetic mean and standard deviation were used. P-value less than or equal 0.05 was considered statistically significant.

Approval was obtained from the ethics committee of faculty of Nursing, Najran University prior to carrying out this study. All participants also had the right to refuse to participate or to withdraw from the study.

\section{Results and Discussion}

Table 1: Distribution of the studied nurses regarding their characteristics $(\mathbf{n}=\mathbf{7 2})$.

\begin{tabular}{|c|c|c|}
\hline Items & Frequency & Percentage \\
\hline \multicolumn{3}{|l|}{ Age / year } \\
\hline $21-25$ & 13 & 18.1 \\
\hline $26-30$ & 30 & 41.7 \\
\hline $31-35$ & 15 & 20.8 \\
\hline $36-40$ & 12 & 16.7 \\
\hline 41 and above & 2 & 2.8 \\
\hline \multicolumn{3}{|l|}{ Gender } \\
\hline Male & 3 & 4.2 \\
\hline Female & 69 & 95.8 \\
\hline \multicolumn{3}{|l|}{ Level of Education } \\
\hline Diploma Nurse & 10 & 13.9 \\
\hline Technical Institute of Nursing & 11 & 15.3 \\
\hline Bachelor of Nursing & 40 & 55.6 \\
\hline Master in Nursing & 11 & 15.3 \\
\hline \multicolumn{3}{|l|}{ Years of Experience } \\
\hline$<1$ & 8 & 11.1 \\
\hline $1-3$ & 6 & 8.3 \\
\hline $4-5$ & 33 & 45.8 \\
\hline $6-7$ & 20 & 27.8 \\
\hline 8 and above & 5 & 6.9 \\
\hline \multicolumn{3}{|l|}{ Work Department } \\
\hline Surgical & 0 & 0 \\
\hline Medical & 11 & 15.3 \\
\hline Outpatient & 5 & 6.9 \\
\hline Intensive Care Unite & 29 & 40.3 \\
\hline Emergency & 27 & 37.5 \\
\hline
\end{tabular}

Source: Authors 
Table 1 shows that less than half of the studied nurses (41.7\%) were between 26 to 30 years old. The majority of them (95.8\%) were females, more than half of them of them $(55.6 \%)$ had bachelor of nursing, and nearly half of them (45.8\%) were have from 4-5 years of experience. In addition, about more than one third of them $(40.3 \%)$ worked in intensive care unit. This study at the same line with study of Mohanty, S. (2016) that reveals that the majority (95\%) of nurses were female nurses (Mohanty, 2016).In addition, this study revealed that more than half of the participants (55.6\%) had bachelor of nursing. This is in agreement with the findings of Al-Sarawan, R. A. L. (2014) in which he concluded that more than half of the studied nurses (56\%) had bachelor of nursing Al-Sarawan, R. A. L. (2014).

Table 2: Distribution of the studied nurse's perception about the causes of medication errors $(n=72)$.

\begin{tabular}{|l|l|l|l|l|}
\hline Items & Yes & No \\
\cline { 2 - 5 } & Frequency & $\mathbf{\%}$ & Frequency & $\mathbf{\%}$ \\
\hline $\begin{array}{l}\text { Drug's error occur when the physician's writing on the doctor } \\
\text { order form is difficult to read }\end{array}$ & 72 & $\mathbf{1 0 0}$ & 0 & 0 \\
\hline $\begin{array}{l}\text { Drug errors occur when nurses are distracted by other patients, } \\
\text { coworker }\end{array}$ & 63 & 87.5 & 9 & 12.5 \\
\hline $\begin{array}{l}\text { Drug errors occur when nurse are did not give the drug to } \\
\text { patient on time }\end{array}$ & 65 & 90.3 & 7 & 9.7 \\
\hline Drug errors occur when nurses are tired and exhausted & 47 & 65.3 & 25 & 34.7 \\
\hline $\begin{array}{l}\text { Drug errors occur when there is confusion between 2 drugs } \\
\text { with similar names }\end{array}$ & 70 & 97.2 & 2 & 2.8 \\
\hline $\begin{array}{l}\text { Drug errors occur when nurses did not have clear instruction } \\
\text { about some drugs }\end{array}$ & 72 & $\mathbf{1 0 0}$ & 0 & 0 \\
\hline $\begin{array}{l}\text { Drug errors occur when the physician prescribed the wrong } \\
\text { dose }\end{array}$ & 64 & 88.9 & 8 & 11.1 \\
\hline $\begin{array}{l}\text { Drug errors occur when the nurse fails to check the patient's } \\
\text { name with the medication administration record }\end{array}$ & 61 & 84.7 & 11 & 15.3 \\
\hline Drug errors occur when the nurse miscalculates the dose & 67 & 93.1 & 5 & 6.9 \\
\hline Drug errors occur when the medication labels are damaged & 72 & $\mathbf{1 0 0}$ & 0 & 0 \\
\hline $\begin{array}{l}\text { Drug errors occur when the nurse sets up or adjusts an infusion } \\
\text { device incorrectly }\end{array}$ & 72 & $\mathbf{1 0 0}$ & 0 & 0 \\
\hline
\end{tabular}

Source: Authors

Regarding nurse's perception about the causes of medication errors, this table showsthat $100 \%$ have good perception about drug's error occur when the physician's writing on the doctor order form is difficult to read, when nurses did not have clear instruction about some drugs, when the medication labels are damaged and when the nurse sets up or adjusts an infusion device incorrectly.

The findings reveal that most of the nurses in the present study referred to different reasons that cause medication errors like drug error occur when there is no clear instruction about some drugs, incorrect sets up or adjusts an infusion device, and miscalculation of the dose. This was supported by the study of Kassar, (2016) which reveals that (90\%) of the nurses agree that drug error occur when nurses did not have clear instruction about some drugs, $(88 \%)$ of the nurses found that drug errors occur when the nurse sets up or adjusts an infusion device incorrectly (Kassar, 2016). 


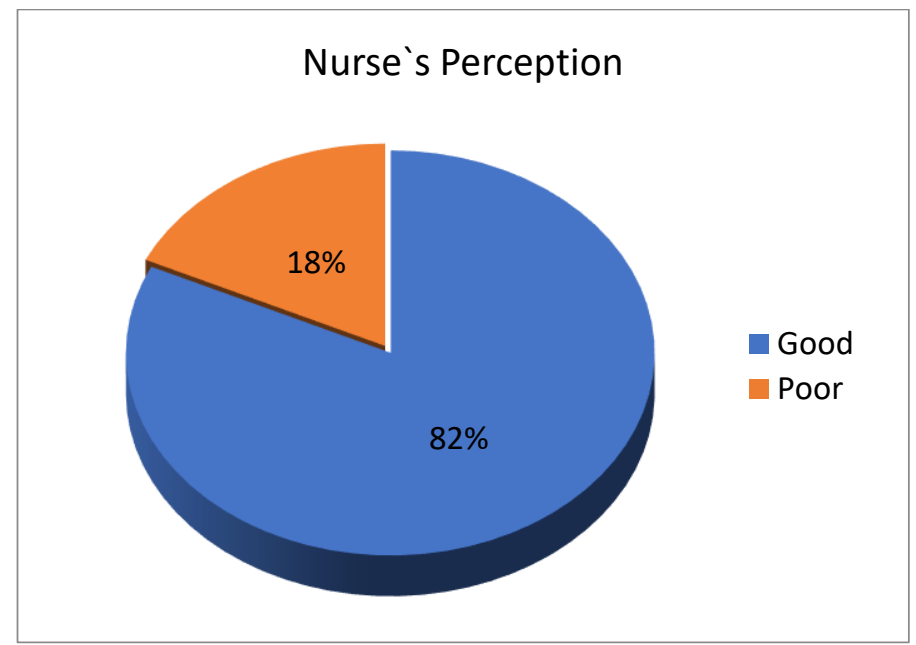

Figure 1: Total number and percentage distribution of the studied nurse's perception about the causes of medication errors $(\boldsymbol{n}=72)$.

It was obvious from a figure that, more than two thirds of the studied nurses (82\%) had good perception about the causes of medication errors, while less than one quarter of them $(418 \%)$ had poor perception about the causes of medication errors.

Table 3: Distribution of the studied nurse's about reporting medication errors when it occurs

$$
(n=72) \text {. }
$$

\begin{tabular}{|l|l|l|l|l|}
\hline \multirow{2}{*}{ Items } & Yes & \multicolumn{2}{l|}{ No } \\
\cline { 2 - 5 } & Frequency & $\mathbf{\%}$ & Frequency & $\mathbf{\%}$ \\
\hline I am usually sure what constitutes a medication error & 72 & $\mathbf{1 0 0}$ & 0 & 0 \\
\hline $\begin{array}{l}\text { I am usually sure when a medication error should be reported } \\
\text { using an incident report }\end{array}$ & 67 & 93.1 & 5 & 6.9 \\
\hline $\begin{array}{l}\text { Some medication errors are not reported because nurses are } \\
\text { afraid of the reaction they will receive from the nurse manager }\end{array}$ & 49 & 68.1 & 23 & 31.9 \\
\hline $\begin{array}{l}\text { Some medication errors are not reported because nurses are } \\
\text { afraid of the reaction they will receive from their peers }\end{array}$ & 44 & 61.1 & 28 & 38.9 \\
\hline $\begin{array}{l}\text { Have you ever failed to report a drug error because nurses did } \\
\text { not think the error was serious to warrant reporting? }\end{array}$ & 8 & 11.1 & 64 & 88.9 \\
\hline $\begin{array}{l}\text { Have you ever failed to report a medication error because you } \\
\text { were afraid you might be subject to disciplinary action or even } \\
\text { lose your job? }\end{array}$ & 3 & 4.2 & 69 & $\mathbf{9 5 . 8}$ \\
\hline
\end{tabular}

Source: Authors

Table 3 presents the response regarding the studied nurses' reporting medication errors this table clarified that; all of them (100\%) were usually sure what constitutes a medication error, while, the majority of them (95.8) had you ever failed to report a medication error because they were afraid they might be subject to disciplinary action or even lose their job. Despite the fact that reporting the ME is very important in order to control those errors and help to identify them and implement the policies and rules to control them and minimize their occurrence, however, studies showed that less than $25 \%$ of medication errors are reported using incidence report(IR) (Pepper, 1995).

Accurate reporting is a very important issue when it comes to prevention of ME, and it depends on individual nurse's decision (Cohen, 2000). Vrbnjak et al. (2016) study showed that errors of both commission and omission go unreported. Failure to administer 
a medication is the most underreported error because nurses perceive that patients will not be harmed in this situation. Conversely, errors resulting in overmedication are the most frequently reported(Vrbnjak et al., 2016).

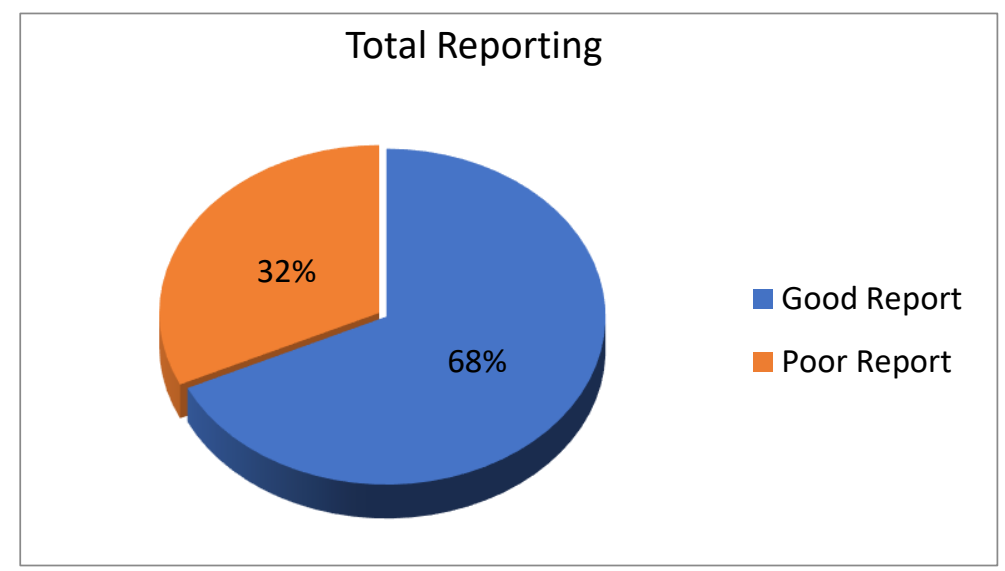

Figure 2: Total number and percentage distribution of the studied nurse's reporting medication errors $(n=72)$.

It was obvious from a figure that, more than two thirds of the studied nurses (66\%) had good reporting medication errors, while, about one third of them (32\%) had reporting medication errors.

Table 4: Distribution of the studied nurse's perceptions of barriers to reporting medication errors

$$
(n=72) \text {. }
$$

\begin{tabular}{|c|c|c|c|c|c|c|c|c|}
\hline \multirow{2}{*}{ Items } & \multicolumn{2}{|l|}{ No Barriers } & \multicolumn{2}{|c|}{ Minor Barriers } & \multicolumn{2}{|l|}{$\begin{array}{l}\text { Moderate } \\
\text { Barriers }\end{array}$} & \multicolumn{2}{|c|}{ Major Barriers } \\
\hline & Frequency & $\%$ & Frequency & $\%$ & Frequency & $\%$ & Frequency & $\%$ \\
\hline $\begin{array}{l}\text { Concerns over the consequences } \\
\text { of reporting }\end{array}$ & 8 & 11.1 & 14 & 19.4 & 48 & 66.7 & 2 & 2.8 \\
\hline Fear of punishment & 5 & 6.9 & 37 & 51.4 & 13 & 18.1 & 17 & 23.6 \\
\hline $\begin{array}{l}\text { Blaming nurses if patients are } \\
\text { harmed }\end{array}$ & 2 & 2.8 & 42 & 58.3 & 16 & 22.2 & 12 & 16.7 \\
\hline $\begin{array}{l}\text { Perceiving medication error as } \\
\text { not important }\end{array}$ & 32 & 44.4 & 29 & 40.3 & 11 & 15.3 & 0 & 0 \\
\hline $\begin{array}{l}\text { No need to report if no patient is } \\
\text { harmed }\end{array}$ & 27 & 37.5 & 29 & 40.3 & 10 & 13.9 & 6 & 8.3 \\
\hline $\begin{array}{l}\text { Too long and time-consuming } \\
\text { reporting }\end{array}$ & 32 & 44.4 & 30 & 41.7 & 7 & 9.7 & 3 & 4.2 \\
\hline
\end{tabular}

Source: Authors

Table 4 shows the analysis of response regarding studied nurse's perceptions of barriers to reporting medication errors this table clarified that, less than half of the studied nurses (44.4\%) had no barriers to perceiving medication error as not important and too long and time-consuming reporting, more than half of them $(58.3 \%)$ had minor barriers to blaming nurses if patients are harmed. In addition, about two thirds of them $(66.7 \%)$ had moderate barriers to concerns over the consequences of reporting. While, about one quarter of them (23.6\%) had major barriers to fear of punishment. 


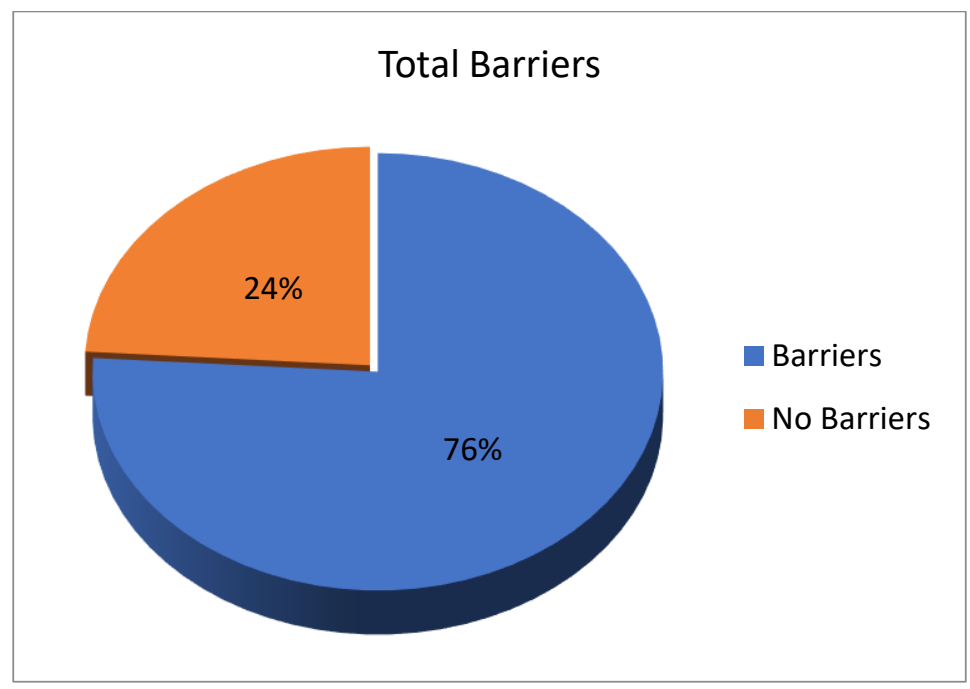

Figure 3: Overall distribution of the studied nurse's perception of barriers to reporting medication errors $(n=72)$.

It was obvious from this figure that, more than three quarters of the studied nurses (76\%) had perception of barriers to reporting medication errors, while less than one quarter of them $(24 \%)$ had not perception of barriers to reporting medication errors.

Table 5: Relation between total scores of the studied nurse's perceptions about the causes of medication errors and their characteristics $(n=72)$.

\begin{tabular}{|c|c|c|c|c|c|c|}
\hline \multirow{2}{*}{\multicolumn{2}{|c|}{ Variables }} & \multicolumn{2}{|l|}{ Good } & \multicolumn{2}{|l|}{ Poor } & \multirow[b]{2}{*}{ P. Values } \\
\hline & & No & $\%$ & No & $\%$ & \\
\hline \multirow{5}{*}{ Age in years } & $21-25$ & 0 & 0 & 13 & 18 & \multirow{5}{*}{ Sig.: 0.644 NS } \\
\hline & $26-30$ & 30 & 41.6 & 0 & 0 & \\
\hline & $31-35$ & 15 & 20.8 & 0 & 0 & \\
\hline & $36-40$ & 12 & 16.6 & 0 & 0 & \\
\hline & 41 and above & 2 & 2.7 & 0 & 0 & \\
\hline \multirow{2}{*}{ Gender } & Male & 3 & 4.1 & 0 & 0 & \multirow{2}{*}{ Sig.: $0.098 \mathrm{NS}$} \\
\hline & Female & 56 & 77.7 & 13 & 18 & \\
\hline \multirow{4}{*}{$\begin{array}{l}\text { Educationa } \\
1 \text { level }\end{array}$} & Diploma Nurse & 8 & 10.6 & 2 & 2.7 & \multirow{4}{*}{$\begin{array}{c}\text { Sig. : } 0.433 \\
\text { NS }\end{array}$} \\
\hline & $\begin{array}{l}\text { Technical Institute of } \\
\text { Nursing }\end{array}$ & 11 & 15.3 & 0 & 0 & \\
\hline & Bachelor of Nursing & 40 & 44.5 & 0 & 0 & \\
\hline & Master in Nursing & 0 & 0 & 11 & 15.3 & \\
\hline \multirow{5}{*}{ Years } & $<1$ & 0 & 0 & 8 & 10.6 & \multirow{5}{*}{ Sig.: 0.783 NS } \\
\hline & $1-3$ & 1 & 1.3 & 5 & 6.9 & \\
\hline & $4-5$ & 33 & 45.8 & 0 & 0 & \\
\hline & $6-7$ & 20 & 27.7 & 0 & 0 & \\
\hline & 8 and above & 5 & 6.9 & 0 & 0 & \\
\hline \multirow{5}{*}{$\begin{array}{l}\text { Work } \\
\text { Department }\end{array}$} & Surgical & 0 & 0 & 0 & 0 & \multirow{5}{*}{ Sig.: 0.422 NS } \\
\hline & Medical & 6 & 8.3 & 5 & 6.9 & \\
\hline & Outpatient & 3 & 4.1 & 2 & 2.7 & \\
\hline & Intensive Care Unite & 23 & 31.9 & 6 & 8.3 & \\
\hline & Emergency & 27 & 37.5 & 0 & 0 & \\
\hline
\end{tabular}

$P$-value $\leq 0.05 *$ statistically significance

Source: Authors 
Table 5 shows the data analysis of the relation between total scores of the studied nurses' perception about the causes of medication errors and their characteristics, this table indicated that, more than two thirds of the studied nurses $(77.7 \%)$ who were female and more than one third of them $(41.6 \%)$ who aged 26 to 30 years old had good perception about the causes of medication errors, also less than half ofthem (44.5\%) who have bachelor degree, nearly half of them $(45.8 \%)$ who have 4 to 5 year of experience and more than one third of them $(37.5 \%)$ who worked in emergency department had good perception about the causes of medication errors. Therefore, there were no statistically significant relation between the studied nurses' perception about the causes of medication errors and their characteristics $(\mathrm{P}>0.05)$.

The study also found their no correlation between nurses' age and their perception of the causes for medication error. In a study to Simonsen et.al (2011) who concluded that medication knowledge unsatisfactory among practicing nurses, with a significant risk for medication errors. The study revealed a need to improve the nurses' basic knowledge, especially when referring to drug management (Simonsen et al., 2011).

Table 6: Relation between total scores of the studied nurse's reporting medication errors and their characteristics (tables 6).

\begin{tabular}{|c|c|c|c|c|c|c|}
\hline \multirow{2}{*}{\multicolumn{2}{|c|}{ Variables }} & \multicolumn{2}{|l|}{ Good } & \multicolumn{2}{|l|}{ Poor } & \multirow{2}{*}{ P. Values } \\
\hline & & \multicolumn{2}{|l|}{ No } & \multicolumn{2}{|l|}{ No } & \\
\hline \multirow{5}{*}{ Age in years } & $21-25$ & 5 & 6.9 & 8 & 11.1 & \multirow{5}{*}{$\begin{array}{c}\text { Sig.: } \\
0.006 \mathrm{~S}\end{array}$} \\
\hline & $26-30$ & 23 & 31.9 & 7 & 9.7 & \\
\hline & $31-35$ & 15 & 20.8 & 0 & 0 & \\
\hline & $36-40$ & 6 & 8.3 & 6 & 8.3 & \\
\hline & 41 and above & 0 & 0 & 2 & 2.7 & \\
\hline \multirow{2}{*}{ Gender } & Male & 3 & 4.1 & 0 & 0 & \multirow{2}{*}{$\begin{array}{c}\text { Sig.: } \\
\text { 0.143 NS }\end{array}$} \\
\hline & Female & 46 & 63.8 & 23 & 31.9 & \\
\hline \multirow{4}{*}{$\begin{array}{l}\text { Educational } \\
\text { level }\end{array}$} & Diploma Nurse & 8 & 11.1 & 2 & 2.7 & \multirow{4}{*}{$\begin{array}{c}\text { Sig. : } \\
0.282 \mathrm{NS}\end{array}$} \\
\hline & Technical Institute of Nursing & 11 & 15.2 & 0 & 0 & \\
\hline & Bachelor of Nursing & 25 & 34.7 & 15 & 20.8 & \\
\hline & Master in Nursing & 5 & 6.9 & 6 & 8.3 & \\
\hline \multirow{5}{*}{$\begin{array}{l}\text { Years of } \\
\text { experience }\end{array}$} & $<1$ & 0 & 0 & 8 & 11.1 & \multirow{5}{*}{$\begin{array}{c}\text { Sig.: } \\
0.016 \mathrm{~S}\end{array}$} \\
\hline & $1-3$ & 5 & 6.9 & 1 & 1.3 & \\
\hline & $4-5$ & 33 & 45.8 & 0 & 0 & \\
\hline & $6-7$ & 11 & 15.2 & 9 & 12.5 & \\
\hline & 8 and above & 0 & 0 & 5 & 6.9 & \\
\hline \multirow{5}{*}{$\begin{array}{c}\text { Work } \\
\text { Department }\end{array}$} & Surgical & 0 & 0 & 0 & 0 & \multirow{5}{*}{$\begin{array}{c}\text { Sig.: } \\
0.145 \text { NS }\end{array}$} \\
\hline & Medical & 11 & 15.2 & 0 & 0 & \\
\hline & Outpatient & 0 & 0 & 5 & 6.9 & \\
\hline & Intensive Care Unite & 11 & 15.2 & 18 & 25 & \\
\hline & Emergency & 27 & 37.5 & 0 & 0 & \\
\hline
\end{tabular}

$P$-value $\leq 0.05 *$ statistically significance

\section{Source: Authors}

Table 6 presents the data analysis regarding relation between total scores of the studied nurse's reporting medication errors and their characteristics, this table indicated that, nearly two thirds of the studied nurses (63.8\%) who were female and nearly one third of them $(31.9 \%)$ who aged 26 to 30 years old had good reporting medication errors, also more than one third of them 
(34.7\%) who have bachelor degree, nearly half of them (45.8\%) who have 4 to 5 year of experience and more than one third of them (37.5\%) who worked in emergency department had good perception about the causes of medication errors. Therefore, there were no statistically significant relation between the studied nurse's reporting medication errors and their characteristics ( $\mathrm{P}>0.05)$ except age and years of experience $(\mathrm{P}<0.05)$.

In this study found that (68\%) of the studied nurses had a good reporting about of medication errors. This findings supported with the study of Kazzar (2016) in the study $(94 \%)$ of the nurses agree that they usually sure when a medication error should be reported using an incident report. In addition, about $88 \%$ of the nurses shows that they usually sure what constitutes a medication error (Kassar, 2016).

Table 7: Relation between total scores of the studied nurse's perceptions of barriers to reporting medication errors and their characteristics

\begin{tabular}{|c|c|c|c|c|c|c|}
\hline \multirow{2}{*}{\multicolumn{2}{|c|}{ Variables }} & \multicolumn{2}{|c|}{ More Barriers } & \multicolumn{2}{|c|}{ Less Barriers } & \multirow{2}{*}{ P. Values } \\
\hline & & No & & No & $\%$ & \\
\hline \multirow{5}{*}{ Age in years } & $21-25$ & 11 & 15.2 & 2 & 2.7 & \multirow{5}{*}{$\begin{array}{c}\text { Sig.: } \\
0.045 \mathrm{~S}\end{array}$} \\
\hline & $26-30$ & 23 & 31.9 & 7 & 9.7 & \\
\hline & $31-35$ & 10 & 13.8 & 5 & 6.9 & \\
\hline & $36-40$ & 9 & 12.5 & 3 & 4.1 & \\
\hline & 41 and above & 2 & 2.7 & 0 & 0 & \\
\hline \multirow{2}{*}{ Gender } & Male & 0 & 0 & 3 & 4.1 & \multirow{2}{*}{$\begin{array}{c}\text { Sig.: } \\
0.375 \mathrm{NS}\end{array}$} \\
\hline & Female & 55 & 76.3 & 14 & 19.4 & \\
\hline \multirow{4}{*}{$\begin{array}{c}\text { Educational } \\
\text { level }\end{array}$} & Diploma Nurse & 5 & 6.9 & 5 & 6.9 & \multirow{4}{*}{$\begin{array}{c}\text { Sig. : } \\
0.195 \text { NS }\end{array}$} \\
\hline & Technical Institute of Nursing & 11 & 15.2 & 0 & 0 & \\
\hline & Bachelor of Nursing & 28 & 38.8 & 12 & 16.6 & \\
\hline & Master in Nursing & 11 & 15.2 & 0 & 0 & \\
\hline \multirow{5}{*}{$\begin{array}{c}\text { Years of } \\
\text { experience }\end{array}$} & $<1$ & 6 & 8.3 & 2 & 2.7 & \multirow{5}{*}{$\begin{array}{c}\text { Sig.: } \\
0.162 \text { NS }\end{array}$} \\
\hline & $1-3$ & 5 & 6.9 & 1 & 1.3 & \\
\hline & $4-5$ & 28 & 38.8 & 5 & 6.9 & \\
\hline & $6-7$ & 14 & 19.4 & 6 & 8.3 & \\
\hline & 8 and above & 2 & 2.7 & 3 & 4.1 & \\
\hline \multirow{5}{*}{$\begin{array}{c}\text { Work } \\
\text { Department }\end{array}$} & Surgical & 0 & 0 & 0 & 0 & \multirow{5}{*}{$\begin{array}{c}\text { Sig.: } \\
0.095 \mathrm{NS}\end{array}$} \\
\hline & Medical & 11 & 15.2 & 0 & 0 & \\
\hline & Outpatient & 2 & 2.7 & 3 & 4.1 & \\
\hline & Intensive Care Unite & 15 & 20.8 & 14 & 19.4 & \\
\hline & Emergency & 27 & 37.5 & 0 & 0 & \\
\hline
\end{tabular}

$P$-value $\leq 0.05 *$ statistically significance

Source: Authors

Table 7 presents the data analysis regarding relation between total scores of the studied nurse's perceptions of barriers to reporting medication errors and their characteristics, this table indicated that, more than two thirds of the studied nurses $(76.3 \%)$ who were female and nearly one third of them (31.9\%) who aged 26 to 30 years old had high perceptions of barriers to reporting medication errors, also, more than one third of them $(38.8 \%)$ who have bachelor degree, more than one third of them (38.8\%) who have 4 to 5 year of experience and more than one third of them $(37.5 \%)$ who worked in emergency department had had high perceptions of barriers to reporting medication errors. Therefore, there were no statistically significant relation between the studied nurse's perceptions of barriers to reporting medication errors and their characteristics $(\mathrm{P}>0.05)$ except age and work department $(\mathrm{P}<0.05)$. 


\section{Conclusion and Suggestion}

Based on the findings of the current study, it can be concluded that more than two thirds of the studied nurses had good perception about the causes of medication errors. There were no statistically significant relation between the studied nurses' perception about the causes of medication errors and their characteristics. In addition, there were no statistically significant relationships between the participants' reporting medication errors and their characteristics except age and years of experience. In addition, there were no statistically significant relationship between the studied nurses' perceptions of barriers to reporting medication errors and their characteristics. Based on the results of this study, it is recommended that the factors that lead to medication errors must be considered by policy makers, and they should set policies and strategies to overcome the factors.

\section{Conflict of Interest}

The authors declare that they have no competing interests

\section{Funding}

This research received no fund.

\section{References}

Flynn, L., Liang, Y., Dickson, G. L., Xie, M., \& Suh, D. C. (2012). Nurses’ practice environments, error interception practices, and inpatient medication errors. Journal of Nursing Scholarship, 44(2), 180-186.

World Health Organization(2007). Patient safety: making health care safer.

Kruer, R. M., Jarrell, A. S., \& Latif, A. (2014). Reducing medication errors in critical care: a multimodal approach. Clinical pharmacology: advances and applications, 6, 117.

Kim, K. S., KWON, S. H., KIM, J. A., \& Cho, S. (2011). Nurses' perceptions of medication errors and their contributing factors in South Korea. Journal of nursing management, 19(3), 346-353.

Tshiamo, W. B., Kgositau, M., Ntsayagae, E., \& Sabone, M. B. (2015). The role of nursing education in preventing medication errors in Botswana. International journal of africa nursing sciences, 3, 18-23.

Spector, J. M., Agrawal, P., Kodkany, B., Lipsitz, S., Lashoher, A., Dziekan, G., ... \& Gawande, A. (2012). Improving quality of care for maternal and newborn health: prospective pilot study of the WHO safe childbirth checklist program. PloS one, 7(5), e35151.

Balkhi, B., AlQahtani, N., Alwhaibi, M., Alshammari, T. M., Alhawassi, T. M., Mahmoud, M. A., ... \& Aljadhey, H. (2017). Prevalence and Factors Associated With Polypharmacy Use Among Adult Patients in Saudi Arabia. Journal of patient safety.

Benjamin, D. M. (2003). Reducing medication errors and increasing patient safety: case studies in clinical pharmacology. The Journal of Clinical Pharmacology, 43(7), 768783.

Cousins, D. D., \& Heath, W. M. (2008). The National Coordinating Council for Medication Error Reporting and Prevention: promoting patient safety and quality through 
innovation and leadership. Joint Commission journal on quality and patient safety, 34(12), 700-702.

Kaushal, R., Bates, D. W., Landrigan, C., McKenna, K. J., Clapp, M. D., Federico, F., \& Goldmann, D. A. (2001). Medication errors and adverse drug events in pediatric inpatients. Jama, 285(16), 2114-2120.

Buckley, M. S., Erstad, B. L., Kopp, B. J., Theodorou, A. A., \& Priestley, G. (2007). Direct observation approach for detecting medication errors and adverse drug events in a pediatric intensive care unit. Pediatric Critical Care Medicine| Society of Critical Care Medicine, 8(2), 145-152.

Deans, C. (2005). Medication errors and professional practice of registered nurses. Collegian, 12(1), 29-33.

Dibbi, H. M., Al-Abrashy, H. F., Hussain, W. A., Fatani, M. I., \& Karima, T. M. (2006). Causes and outcome of medication errors in hospitalized patients. Saudi medical journal, 27(10), 1489.

Al-Shara, M. (2011). Factors contributing to medication errors in Jordan: a nursing perspective. Iranian journal of nursing and midwifery research, 16(2), 158.

Al-Sarawan, R. A. L. (2014). Medication errors: Nurse's Perceptions of main types and leading factors, and reporting attitudes in North West Bank Governmental Hospitals (Doctoral dissertation).

Güneş, Ü. Y., Gürlek, Ö., \& Sönmez, M. (2014). Factors contributing to medication errors in T urkey: nurses' perspectives. Journal of nursing management, 22(3), 295-303.

Mohanty, S. (2016). Awareness of medication error, medication management and prevention among staff nurses in IMS \&Sum Hospital, Odisha. Nitte University Journal of Health Science, 6(4), 18.

Kassar, R. A. H. A. (2016). Nurses' perceptions of drug errors in Hospitals, International Journal of Scientific and Research Publications, Volume 6, Issue 11, November 2016 584-589.

Pepper G.(1995).. Errors in drug administration by nurses. American Journal of HealthSystem Pharmacy. 52(4):390-5.

Cohen, M. R. (2000). Why error reporting systems should be voluntary: they provide better information for reducing errors.

Vrbnjak, D., Denieffe, S., O’Gorman, C., \& Pajnkihar, M. (2016). Barriers to reporting medication errors and near misses among nurses: A systematic review. International journal of nursing studies, 63, 162-178.

Simonsen, B. O., Johansson, I., Daehlin, G. K., Osvik, L. M., \& Farup, P. G. (2011). Medication knowledge, certainty, and risk of errors in health care: a cross-sectional study. BMC Health Services Research, 11(1), 1-9. 